
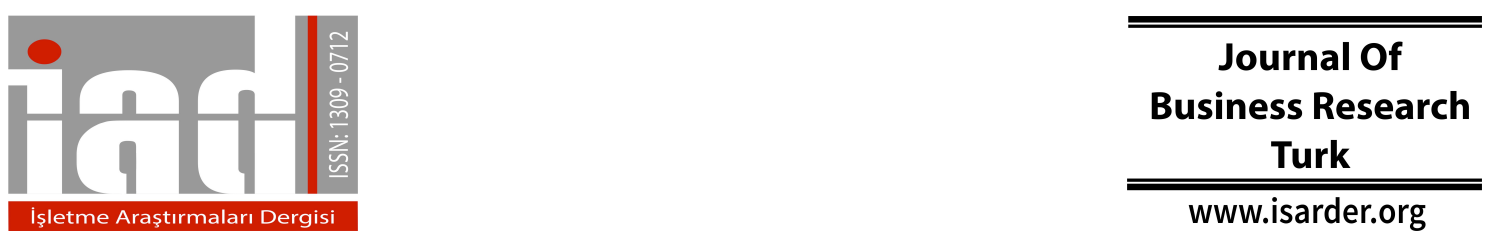

\title{
A Pilot Study on Validity of Turkish Version of Organizational Politics Scale
}

\author{
Füsun ÇINAR ALTINTAŞ \\ Uludag University \\ Economics and Administrative Sciences Faculty \\ Business Administration Department \\ Nilüfer, Bursa, Turkey \\ fcinar@uludag.edu.tr
}

\begin{abstract}
The present study aimed to pilot test the reliability and construct validity of the Turkish version of the Perception of Organizational Politics Scale (short version), developed by Kacmar and Carlson (1997). Study sample included 199 executive and non-executives employees working in different industries in Bursa. Statistical analysis results supported the scale's one dimensional and three dimensional 13-item structure and the corrected model was shown to be more reliable and valid.
\end{abstract}

Keywords: Perception of Organizational Politics, Organizational Politics Scale, reliability analysis, confirmatory factor analysis

\section{Introduction}

The phenomenon of politics is a reality that exists in the daily activities of organizations (Ferris and Kacmar, 1992; Kacmar and Carlson, 1997). Despite the fact that early studies on organizational theory relied on the assumption that rational principles dominated in organizational operations and individual behavior (Altıntaş Çınar, 2007), constantly changing environmental conditions and competitive environment, limited operational resources and technological changes provide a setting for irrational behavior in the organizations. In fact, certain research stated that organizational operations and behavior of the individuals would not be always rational and irrational behavior could be observed from time to time in the literature (Gandz and Murray, 1980; Madison et al., 1980; Pfeffer 1981; Mintzberg, 1983; Welsh and Slusher, 1986, Eisenhardt and Burgeois, 1988; Drory and Romm, 1988; Parker et al., 1995). Thus, it could be argued that irrational properties politicize the organizations and political behavior of the individuals render the organizations irrational.

Ideas about organizational politics became a part of the literature since 1960's. Although several empirical, theoretical and conceptual studies have been conducted on the subject, organizational politics is yet to be conceptualized. On the other hand, definitions of the concept focused primarily on the phenomenon of effect (Mayes and Allen, 1977; Farrel and Petersen 1982). Since organizational resources are limited, self- 
interest of individuals in their activities and their efforts and activities to affect other individuals-employees based on their own interest form the basis of the organizational politics concept. Especially the behavior that are not approved by the organization and conducted with the aim to influence the decision making process are considered within this context (Burns, 1961; Farrel and Peterson, 1982; Gandz and Murray, 1980; Mayes and Allen, 1977; Schein, 1977; Drory and Romm, 1990). In this framework, Pfeffer and Salancik (1974: 138) stated that decisions on the distribution of limited resources between the organizational sub-units are among the most important decisions in almost all organizations and these decisions are part of a political process. It could be argued that individuals attempt to influence especially topics such as the decision making process about determination of operational budget, selection and evaluation criteria, distribution of awards and tasks and career planning. According to Farrel and Petersen (1982: 405), organizational politics is the process of the attempts to influence the distribution of advantages and disadvantages in an organization. On the other hand, Grey and Ariss (1985: 707) defined organizational politics as the deliberate acts of influence that individuals or groups perform to protect or improve their interests when a conflict situation is present. These effects are not rational according to Miles (1980: 154) and affect the decision making process since the actors focus on their own interests. Furthermore, this process of influence occurs by the use of power tactics (Drory and Romm; 1990). Thus, political behavior differentiates from formal internal behavior and are associated with the non-formal aspect of the organization (Farrell and Peterson, 1982; Narayanan and Fahey, 1982; Mintzberg and Waters (1985); Mayes and Allen (1977: 675) separated the organizational politics into the categories of those approved by the organizations and not approved by the organization and defined political behavior as the methods of arriving at consequences not approved by the organization or arriving at consequences approved by the organization using means that are not approved by the organization. In fact, Pfeffer (1981), called political behavior as hidden motive. According to Pfeffer, the actor believes that the real motive is unacceptable and wrong and hides the real motive and exhibits an acceptable motive. Therefore, political behavior includes the hidden intent that is behind the observable behavior of the actors. Thus, the objective of the present study is to introduce the concept of organizational politics and propose a tool of measurement to assess organizational politics perception in Turkey. For this purpose, reliability and validity of the Turkish translation of "Organizational Politics Perception Scale," developed by Kacmar and Carlson (1997) were investigated. As a result of this assessment, it was considered that if the scale is to be found adequate, it would contribute to establishment of language and methodology unity and facilitate the comparison of study findings obtained from different industries and demographical samples.

\section{The Perception of Organizational Politics}

When the content of organizational politics is observed, a process where individual perceives the situations or events based on her or his own perspective could be noticed (Ferris et al., 1989; Ferris and Kacmar, 1992; Gandz and Murray, 1980; Kacmar and Carlson, 1997). Perception of politics could be defined as subjective interpretation of organizational application that promotes political behavior and the working frame defined by superiors and colleagues (Harrell-Cook et al., 1999: 1095). According to Andrews and Kacmar (2001), perception of politics is generally in the eye of the beholder and the perception could change from one individual to another. While a 
behavior could be conceived as political by someone, for someone else, the same behavior could not be at all political. Even, the same behavior could be perceived as political when performed by others, but it was reported that when the same behavior is performed by the individual, it is unlikely that the behavior would be perceived as political by the same individual (Kacmar and Ferris, 1991). In fact, Gandz and Murray (1989) argued that it would not be possible to have an objective perspective on organizational politics since the perception of politics is based on subjective evaluations that are shaped due to the mood of the individual. Thus, the fact that the perception of politics is more significant that the actual existence of politics is due to fact that individuals shape their responses based on the way they perceive the reality, not based on the objective reality (Cropanzano et al., 1997: 161). Perception of politics depends on how individuals interpret the organizational climate and how political they perceive the work environment and thus, the organizational politics phenomenon is based on the thoughts of individuals about politics rather than the actual existence of politics (Vigoda and Cohen, 2002: 311-312). Ferris et al. (1995) stated that organizational environment has a profound effect on whether individual behavior would be perceived as political. Individuals who perceive the organizational environment as highly political attempt to behave politically as a control mechanism and try to render their environment bearable (Bodla and Danish, 2009: 47). Since organizational culture would be shaped under the influence of political activities in organizations with dense political activities, it could be argued that this would in turn increase the tendency of employees to act politically (Buenger et al., 2007:294). In fact, political perception of the organization by the individual could also result in internal policies independent of the existence of politics in the very organization. At this point, individuals' perception of politics is more important than the actual existence of politics (Bodla and Danish, 2009: 46). It could be observed that there were only limited studies in the literature on measurement of organizational politics perception until the nineties. Especially with the years 1990 and 2000 , interest in organizational politics has been more conceptual, in an increasing number of empirical research, what people think about political tactics, understanding the organizational tactics to influence policy rather than through individual perception, it is important (Vigoda-Gadot and Talmud, 2010: 2832). Kacmar and Ferris (1992) claimed that this was due to the lack of an effective measurement tool for the perceptions of policies in an organization. It could be observed that initial studies on the measurement of the perception of politics were conducted by Gandz and Murray (1980) and Madison et al. (1980). Later on, Perception of Organizational Politics Scale (POPS) was developed by Kacmar and Ferris (1991). Widely applied scale includes 31 statements. The authors conducted their studies in two consecutive stages and arrived at a scale structure where the statements were grouped under five dimensions of "go along to get ahead", "self-serving behavior", "co-workers", "cliques" and "pay and promotion". The scale developed by Kacmar and Ferris was later tested by themselves and many other researchers. In fact, in a study Kacmar and Carlson (1997) conducted on three different samples to improve advanced structural validity of the scale, they stated that three-dimensional and 13 item measurement models were valid. The scale was finalized with a structure where the statements were categorized under three dimensions of "general political behavior", "go along to get ahead" and "pay and promotion". 


\section{Methodology}

The main goal of the study is to test the construct validity of 13 items Organizational Politcs Scale developed by Kacmar and Carlson (1997) as first and second-order models. The study focuses on determining whether the scale works in the contextual of cross section sampling data.

\subsection{Scale and Method}

In the present study, perception of organizational politics scale, short version, developed by Kacmar and Carlson (1997) was translated into Turkish and used. Current scale includes 13 items on general political behavior (6 items), go along get ahead (5 items), and pay and promotion (2 items). The scale is a 5-item Likert-type scale ( $1=\mathrm{I}$ strongly disagree, 2 = I disagree, 3 = I Neutral, $4=$ I agree, and $5=$ I strongly agree). The items of the organizational politic scale used in the study are below.

\section{Table 1: The Items of Organizational Politics Scale}

1. When if comes to pay raises and promotion decisions, policies are irrelevant.
2. Agreeing with powerful others is the best alternative in this organization.
4. Promotions around here are not valued much because how they are determined is so political.
5. I have seen changes made here that only serve the purposes of a few individuals, not the whole work
unit or department.
6. Sometimes it is easier to remain quiet than to fight the system.
7. Favoritism, rather than merit, determines who gets good raises and promotions around here.
8. Telling others what they want to hear is sometimes better than telling the truth.
9. It is safer to think what you are told than to make up your own mind.
10. Inconsistent with organizational policies, promotions in this organization generally do not go to top
performers.
11. None of the raises I have received are consistent with the policies on how raises should be
determined.
12. This organization is not known for its fair pay and promotion policies.
13. Rewards such as pay raises and promotions do not go to those who work hard.
14. The stated pay and promotion polices have nothing to do with how pay raises and promotions are
determined.

The scale is widely accepted and used in organizational politics the literature. The original scale consists three dimensions with 13 items. However, it is measured by only one dimension of construct (Lau et al., 2017; Grave et al., 2015; Y1lmaz et al., 2014) or by fewer items (Saleem, 2015; Nasurdin et al.,2014; Alkan and Turgut, 2015; Y1lmaz, 2014). In this study, the scale was considered three factor with 13 items. In this context, three-dimension (first-order correlated or second-order) and one dimension (all 13 items loaded as one construct) measurement models were compared to clarify the construct validity by exploratory and confirmatory factor analysis, composite reliability and 
average variance extracted (AVE) values. IBM-SPSS 23.0 and AMOS 23.0 statistical software were preferred for analyses.

\subsection{Sample}

The research was carried out by means of conveniant sampling in the Bursa region. 210 employees who are working in businesses operating in different sectors and who are not managers and managers are employed and valid 199 question form was included in the analyzes. Seventy eight percent of the participants worked in manufacturing and $22 \%$ worked in service industries. Industrial distribution of the participants showed that $22 \%$ were in banking, $30 \%$ were in automotive, $28 \%$ were in textile, $15 \%$ were in food and $5 \%$ were in construction industries. Sixty seven percent of the participants were male and $33 \%$ were female. Fifty five percent of the participants were between the ages of $18-35,32 \%$ were between $36-45$ and $11 \%$ were between $46-$ 55 . Work experience of the participants was 1-3 years for $22 \%, 4-8$ years for 38\%, 9-13 years for $12 \%$, and 14 years or more for $18 \%$. Thirteen percent of the participants were junior managers, $26 \%$ were administrative staff, $42 \%$ were middle level managers, and $19 \%$ were top executives.

\subsection{Analysis}

\subsubsection{Data Purification}

In the analysis section, items-based correlations were determined to check multicollinearity problem as shown in Table 2 . There is no correlation value which exceed 0.90 limit. It was not observed. Secondly, the missing values examined were by EM method and then normal distribution values (skewness-kurtosis) were organized. Next the overall cronbach alpha value of the scale was found as 0.859

Table 2: Correlations Between the Study Variables $(\mathrm{N}=199)$

\begin{tabular}{|c|c|c|c|c|c|c|c|c|c|c|c|c|c|c|}
\hline & $\overline{s 1}$ & s2 & $\mathbf{s 3}$ & s4 & s5 & s6 & s7 & s8 & s9 & $\mathbf{s 1 0}$ & s11 & $\mathrm{s12}$ & s13 & $\overline{\mathbf{M}}$ \\
\hline s1 & 1 &, $17^{*}$ &, $33^{* *}$ &, $35^{* *}$ &, $26^{* *}$ &, $34^{* *}$ & 0,13 &,$- 15^{*}$ &, $42^{* *}$ &, $29^{* *}$ &, $26^{* *}$ &, $37^{* *}$ &, $49^{* *}$ & 2,77 \\
\hline s2 & & 1 &, $17^{*}$ &, $39^{* *}$ &, $30^{* *}$ &, $43^{* *}$ & 0,08 &, $25^{* *}$ &, $25^{* *}$ &, $24^{* *}$ &, $24^{* *}$ &, $30^{* *}$ &, $30^{* *}$ & 3,24 \\
\hline s3 & & & 1 &, $33^{* *}$ &, $27^{* *}$ &, $38^{* *}$ & 0,01 &, $14^{*}$ &, $31^{* *}$ &, $47^{* *}$ &, $20^{* *}$ &, $25^{* *}$ &, $32^{* *}$ & 3,14 \\
\hline s4 & & & & 1 &, $38^{* *}$ &, $60^{* *}$ & 0,11 & 0,1 &, $41^{* *}$ &, $30^{* *}$ &, $33^{* *}$ &, $30^{* *}$ &, $32^{* *}$ & 2,94 \\
\hline s5 & & & & & 1 &, $42^{* *}$ &, $28^{* *}$ &, $16^{*}$ &, $33^{* *}$ &, $24^{* *}$ &, $19^{* *}$ &, $17^{*}$ &, $25^{* *}$ & 3,11 \\
\hline s6 & & & & & & 1 & 0,11 & 0,05 &, $55^{* *}$ &, $396^{* *}$ &, $39^{* *}$ &, $37^{* *}$ &, $41^{* *}$ & 3,02 \\
\hline s7 & & & & & & & 1 & 0 &, $32^{* *}$ & 0 & 0,02 &, $21^{* *}$ &, $19^{* *}$ & 2,9 \\
\hline s8 & & & & & & & & 1 & $-0,09$ &, $32^{* *}$ & 0,07 &,$- 15^{*}$ & $-0,11$ & 2,38 \\
\hline s9 & & & & & & & & & 1 &, $346^{* \mathrm{e}^{*}}$ &, $32^{* *}$ &, $63^{* *}$ &, $48^{* *}$ & 2,98 \\
\hline s10 & & & & & & & & & & 1 &, $33^{* *}$ &, $30^{* *}$ & ,297** & 2,92 \\
\hline s11 & & & & & & & & & & & 1 &, $33^{* *}$ &, $18^{* *}$ & 2,82 \\
\hline s12 & & & & & & & & & & & & 1 &, $52^{* *}$ & 3 \\
\hline s13 & & & & & & & & & & & & & 1 & 3,13 \\
\hline$* \mathrm{p}<0$ & & & $<0.01$ & & & & & & & & & & & \\
\hline
\end{tabular}




\subsubsection{Exploratory and Confirmatory Factor Analysis}

An exploratory factor analysis was performed primarily on the data obtained from the study in order to determine the construct validity of the scale. In the exploratory factor analysis, some principles were accepted; principal component, varimax rotation, cross-loadings, factor loadings $>.30$ and scree-plot. In the confirmatory factor analysis, goodness of fit indexes and CR and AVE values were taken into account. RMSEA is expected to be <.05, CFI $>.90$, GFI $>.90$, chi-square / df $<3.0$ (Bentler, 1990; Schermelleh, Engel et al., 2003).

\subsubsection{Exploratory and confirmatory factor analysis: One Dimension}

Scale items were subjected to exploratory factor analysis as one dimension. Initially the 13 items in the organizational politics scale were analyzed as a single dimension. Total variance of the single dimensional scale was found as $36 \%$ as a result of the conduct.ed explanatory factor analysis. Internal consistency of the scale was $\alpha=$ $.836(\mathrm{KMO}=832)$.

Table 3: One Dimensional Factor Analysis

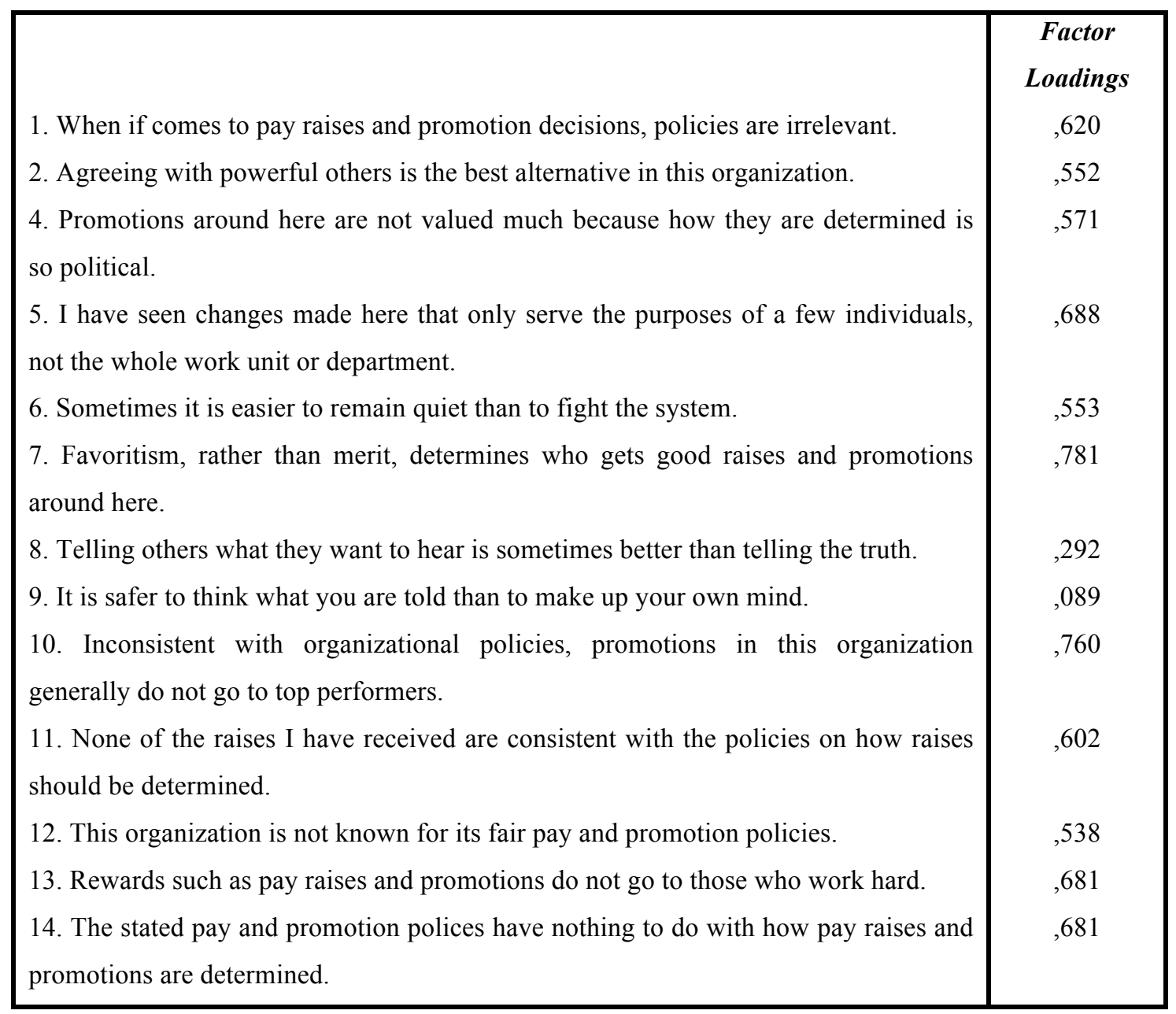

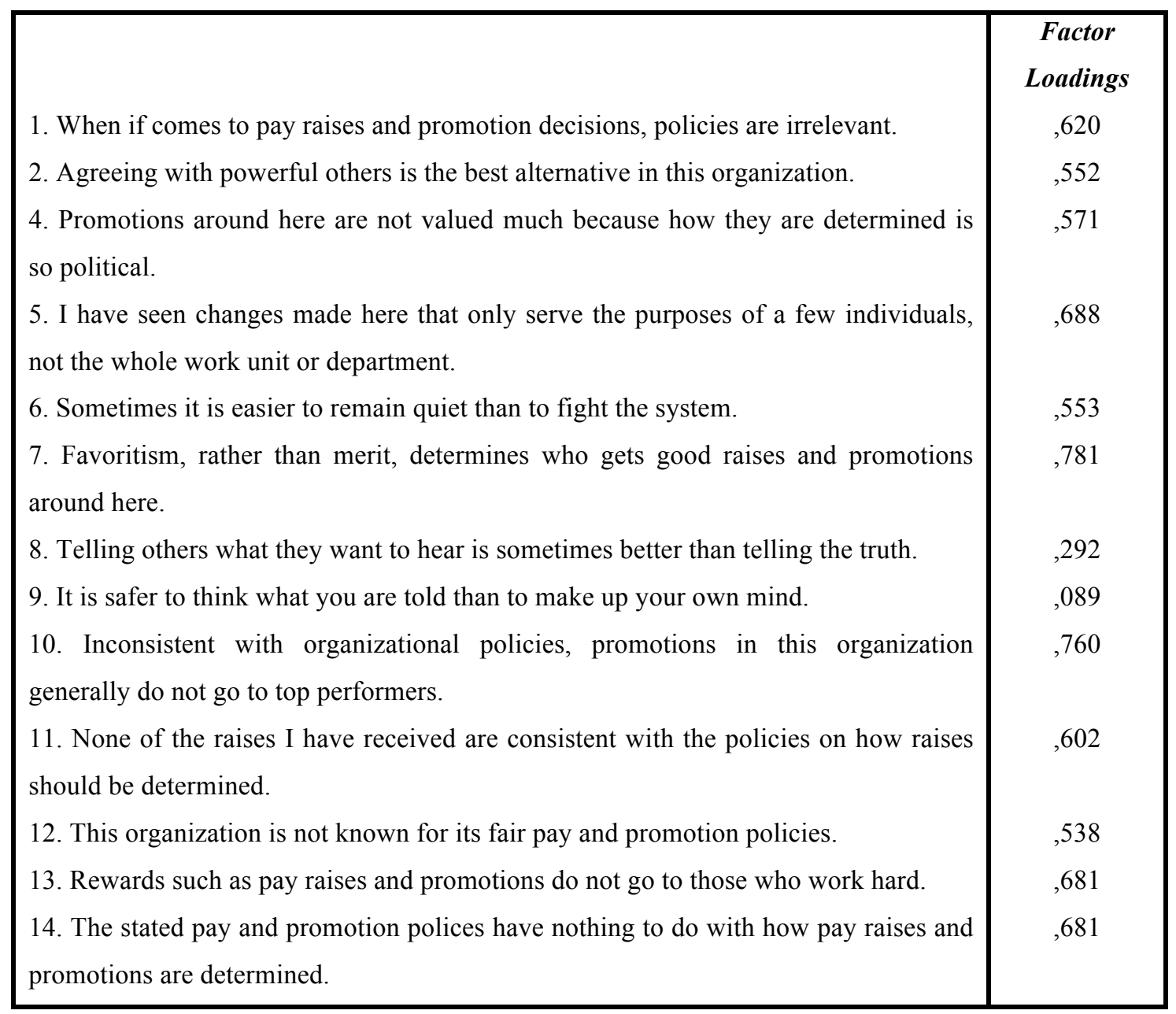

Validity values for the model compliance of the single dimensional scale conducted with confirmatory factor analysis had quite high values after the variable number $8^{\text {th }}$ item and $9^{\text {th }}$ item which had an insignificant effect based on corrected 
validity values, was excluded and covariance of the error terms were taken into account $(\mathrm{GFI}=.963 \mathrm{CFI}=992 \mathrm{RMSEA}=.02 \mathrm{prob}=.250 \mathrm{chi}$-square $/ \mathrm{df}=1,14$ (See Figure 1$)$.

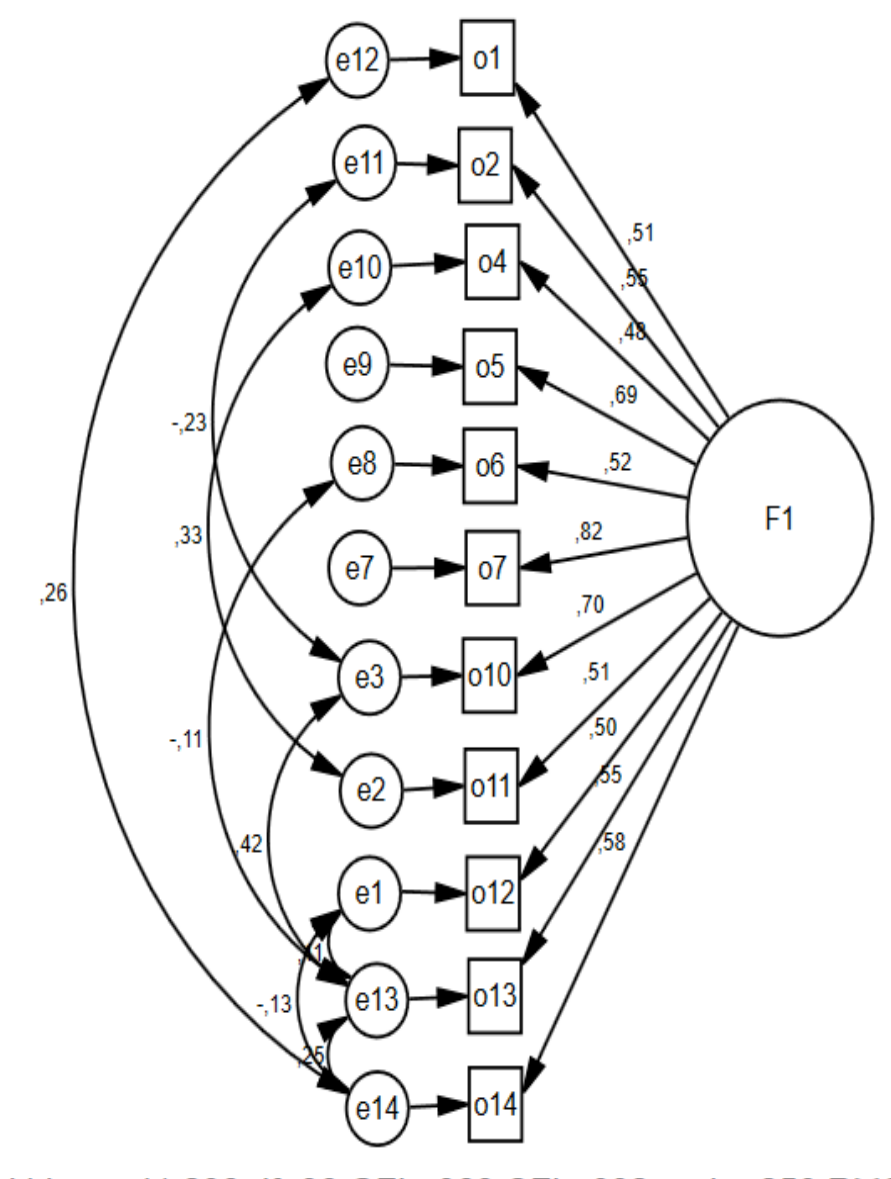

ki-kare $=41,298 \mathrm{df}=36 \mathrm{GFI}=, 963 \mathrm{CFI}=, 992$ prob= 250 RMSEA $=, 027$

Figure 1: One-dimensional Confirmatory Factor Analysis

\subsubsection{Exploratory and Confirmatory Factor Analysis: Three-Dimension}

Total variance of the three-factor organizational politics scale was found as 54, $9 \%$ as a result of the conducted exploratory factor analysis $(\mathrm{KMO}=832)$. The first factor explained $35,8 \%$ of the variance and had an internal consistency value of $\alpha=.800$ and it included five items (items no. 1,9,10,13,14). The second factor explained 12, 20\% of the variance and had an internal consistency value of $\alpha=.756$ and it included five items (items no. 4,5,7,11,12). The third factor explained $8,96 \%$ of the variance and had an internal consistency value of $\alpha=.574$ and it included three items (items no. 2,6,8). 
Table 4: Three Dimensional Factor Analysis

\begin{tabular}{|c|c|c|c|}
\hline & Factor 1 & Factor 2 & Factor 3 \\
\hline $\begin{array}{l}\text { 1. When if comes to pay raises and promotion decisions, policies } \\
\text { are irrelevant. }\end{array}$ & .648 & & \\
\hline $\begin{array}{l}\text { 9. It is safer to think what you are told than to make up your own } \\
\text { mind. }\end{array}$ & -.577 & & \\
\hline $\begin{array}{l}\text { 13. Rewards such as pay raises and promotions do not go to those } \\
\text { who work hard. }\end{array}$ & .718 & & \\
\hline $\begin{array}{l}\text { 14. The stated pay and promotion polices have nothing to do with } \\
\text { how pay raises and promotions are determined. }\end{array}$ & .751 & & \\
\hline $\begin{array}{l}\text { 10. Inconsistent with organizational policies, promotions in this } \\
\text { organization generally do not go to top performers. }\end{array}$ & .682 & & \\
\hline $\begin{array}{l}\text { 4. Promotions around here are not valued much because how they } \\
\text { are determined is so political. }\end{array}$ & & .640 & \\
\hline $\begin{array}{l}\text { 5. I have seen changes made here that only serve the purposes of a } \\
\text { few individuals, not the whole work unit or department. }\end{array}$ & & .454 & \\
\hline $\begin{array}{l}\text { 7. Favoritism, rather than merit, determines who gets good raises } \\
\text { and promotions around here. }\end{array}$ & & .512 & \\
\hline $\begin{array}{l}\text { 12. This organization is not known for its fair pay and promotion } \\
\text { policies. }\end{array}$ & & .765 & \\
\hline $\begin{array}{l}\text { 11. None of the raises I have received are consistent with the } \\
\text { policies on how raises should be determined. }\end{array}$ & & .514 & \\
\hline $\begin{array}{l}\text { 2. Agreeing with powerful others is the best alternative in this } \\
\text { organization. }\end{array}$ & & & .525 \\
\hline 6. Sometimes it is easier to remain quiet than to fight the system. & & & .726 \\
\hline $\begin{array}{l}\text { 8. Telling others what they want to hear is sometimes better than } \\
\text { telling the truth. }\end{array}$ & & & .694 \\
\hline Explained Variance \% & 35.8 & 12.20 & 8.96 \\
\hline Cron.Alpha & .800 & .756 & .574 \\
\hline
\end{tabular}

Three-dimensional confirmatory factor analysis was conducted as first-order correlated model and revised model with modification (dropped two items, 8 and 9). The result can be shown in Figure 2. All values are in acceptable limits (GFI $=.968$ CFI $=.988 \mathrm{RMSEA}=.03 \mathrm{prob}=.193 \mathrm{chi}$-square $/ \mathrm{df}=1.23$ ). It was also conducted a secondorder model based on this revised first-order correlated model. The measurement model of second-order is in Figure 3. Second-order model was preferred as all values were same with first-order model. 
F. Çınar Altıntaş 9/2 (2017) 1-13

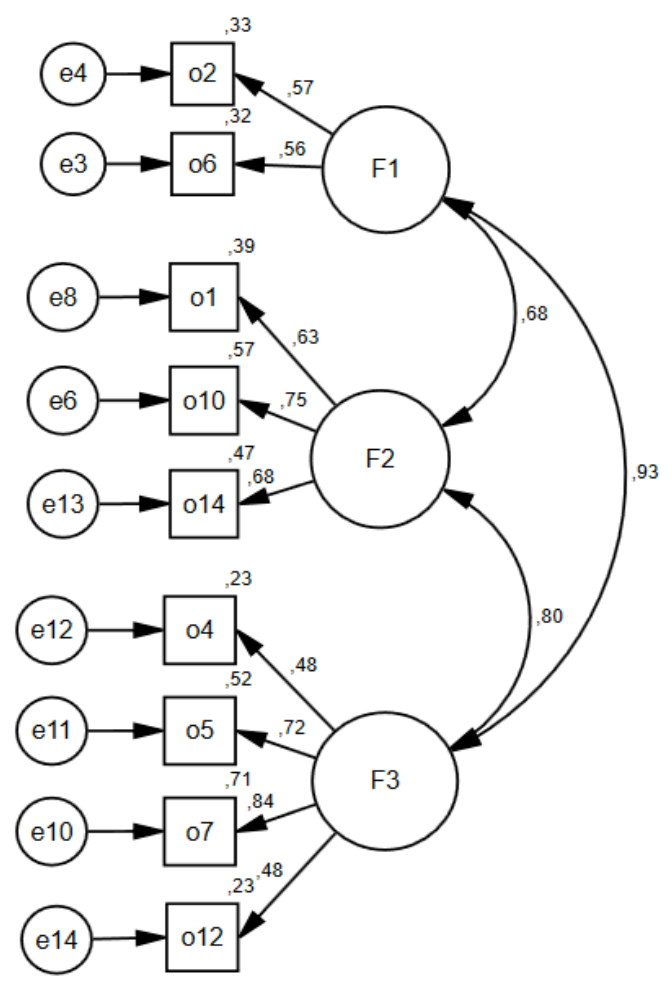

ki-kare=29,753 df=24 prob=,193 GFI=,968 CFI=,988 RMSEA=,035

Figure 2. First-order CFA Correlated

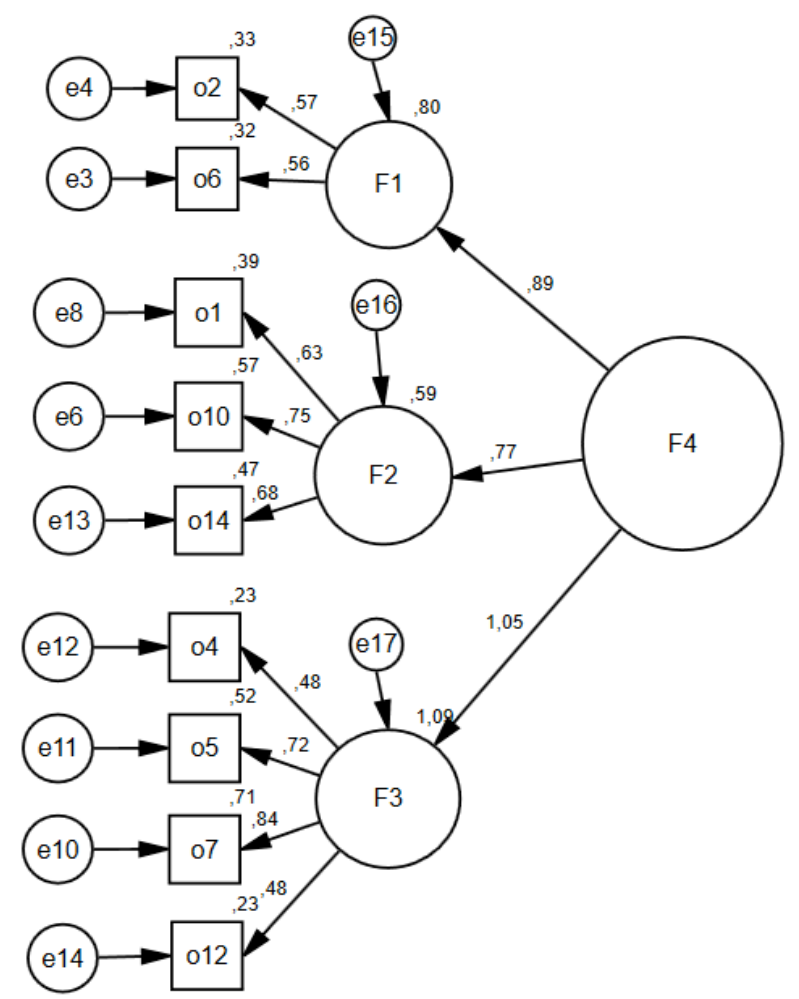

ki-kare=29,753 df=24 prob=,193 GFI=,968 CFI=,988 RMSEA=,035

Figure 3. Second-order CFA 
Tablo: 5 Comparison of The Models

\begin{tabular}{|c|c|c|c|c|c|c|c|}
\hline & $\begin{array}{c}\text { Chi-square } \\
\text { /df }\end{array}$ & CFI & GFI & RMSEA & prob & CR & AVE \\
\hline Model 1: Single-factor & 1,14 & .992 & .963 & .02 & .250 & .67 & .34 \\
\hline $\begin{array}{c}\text { Model 2: Three-factor } \\
\text { (revised) }\end{array}$ & 1.23 & .988 & .968 & .03 & .193 & .73 & .41 \\
\hline \begin{tabular}{c} 
Model 3: Second-order \\
\hline
\end{tabular} & 1.23 & .988 & .968 & .03 & .193 & .92 & .82 \\
\hline
\end{tabular}

As a result, second-order model was selected to validity according to limit of composite reliability, AVE (Hair et al., 1998; Bagozza of and Yi, 1988 and the other indices values. Spesifically, second-order model can be used for conceptualization and simplification of scale.

\section{Results}

The study was carried out to test the validity of the organizational politic scale designed by Kacmar and Carlson(1997) in terms of one and multi-dimensionality. First, exploratory factor analysis was applied to the original scale items and has reached a three-factor solution. Then confirmatory factor analysis performed single and threedimensional (first and second order) the validity were examined. EFA was for group the items, CFA was used to reach to a theoretically-meaningful structure (Byrne, 2005: 17). In this context the contribution of this study is to establish generalized measurement model. Analysis has indicated that second-order model was more valid for the scale as the conceptualization. The basic reason to considering of accept the second-order model is to be reflect meta-evaluation(Chen et al., 2006: 193), simplify parsimonious (Chu, 2008: 322; Hagger and Chatzisarantis, 2005: 527; Rindskopf and Rose, 1988: 66) and generalization (Bagozzi et al. 2001: 33) of the concept. Second-order model is exogenous and unobserved, first-order is endogenous (Narayan et al., 2008: 472).In other words, organizational politic concept has three latent factors and represent subfactors whole. It means that these three factor form the organizational politics together.

It is seen that some article has used the first-order with three-factor model to measure the organizational politics scale of Kacmar and Carlson (1997) and found similar construct in Turkish sampling (Evrim, 2015: 73). The fact that different samplings need to be used to test the stability of a factor structure (Thomson, 1989) is very important for future research in Turkish version of the scale. In this context, testing the scale with different sampling in Turkey will support to reach a valiable measurement for this scale. It will also contribute to Turkish literature of organizational politics field. There are some limitation in research. Finally, it could be argued that to be able to use Perception of Organizational Politics Scale Turkish Version as a standard tool, it should be improved. Therefore, a measurement tools suitable for the cultural context of our country could contribute to future studies. However, the most appropriate stance on the issue is to develop unique scales that are suitable for our culture. Otherwise, as long as we do not develop appropriate scales, improvement of adapted scales could fell short for the purpose. 


\section{References}

Alkan, S. E., and Turgut, T. (2015); A Research about the Relationship of Psychological Safety and Organizational Politics Perception with Compulsory Citizenship Behavior and The Pressures Behind Compulsory Citizenship Behavior, Research Journal of Business and Management, 2(2), 185-203.

Altıntaş, Çınar, F. (2007). Örgüt Yapısının Örgütsel Politika ve İşlem Adaleti Üzerine Etkisinin Yapısal Denklem Modellemesi Yardımıla Analizi, Anadolu Üniversitesi Sosyal Bilimler Dergisi, Cilt/Vol.7- Say1/No: 2: 151-168.

Andrews, M. C., and Kacmar, K. M. (2001). Discriminating among Organizational Politics, Justice, and Support. Journal of Organizational behavior, 22(4), 347366.

Bagozzi, R. P. and Yi, Y. (1988); On the Evaluation of Structural Equation Models, Journal of the Academy of Marketing Science, Vol. 16, No. 1, 74-94.

Bagozzi, R. P., Lee, K. H., \& Van Loo, M. F. (2001). Decisions to Donate Bone Marrow: The Role of Attitudes and Subjective Norms Across Cultures. Psychology and Health, 16(1), 29-56.

Bentler, P. M. (1990); Comparative Fit Indexes in Structural Models, Psychological Bulletin, 107(2), 238.

Bodla, M. A., and Danish, R. Q. (2009); Politics and Workplace: An Empirical Examination of The Relationship Between Perceived Organizational Politics and Work Performance, South Asian Journal of Management, 16(1), 44.

Buenger, C. M., Forte, M., Boozer, R. W., and Maddox, E. N. (2014); A Study of The Applicability of The Perceptions of Organizational Politics Scale (POPS): for Use in The University Classroom, Developments in Business Simulation and Experiential Learning, 34.

Burns, T. (1961); Micropolitics: Mechanisms of Institutional Change. Administrative Science Quarterly, 257-281.

Byrne, B. M. (2005); Factor Analytic Models: Viewing The Structure of An Assessment Instrument From Three Perspectives, Journal of Personality Assessment, 85(1), 17-32.

Chen, F. F., West, S. G., and Sousa, K. H. (2006); A Comparison of Bi-factor and Second-Order Models of Quality of Life, Multivariate Behavioral Research, 41(2), 189-225.

Chu, K. H. L. (2008); A Factorial Validation of Work Value Structure: Second-Order Confirmatory Factor Analysis and its Implications, Tourism Management, 29(2), 320-330.

Cropanzano, R., and Greenberg, J. (1997); Progress in Organizational Justice: Tunneling Through The Maze, International Review of Industrial and Organizational Psychology, 12, 317-372.

Drory, A., and Romm, T. (1988);Politics in Organization and its Perception within The Organization, Organization Studies, 9(2), 165-179.

Drory, A., and Romm, T. (1990); The Definition of Organizational Politics: A Review. Human Relations, 43(11), 1133-1154. 
Eisenhardt, K. M., and Bourgeois, L. J. (1988); Politics of Strategic Decision Making in High-Velocity Environments: Toward A Midrange Theory. Academy of Management Journal, 31(4), 737-770.

Evrim, E. R. O. L. (2015); Perceptions of Organizational Politics Scale (POPS) Questionnaire into Turkish: A Validity and Reliability Study, International Journal of Assessment Tools in Education (IJATE), 2(1).

Farrell, D., and Petersen, J. C. (1982); Patterns of Political Behavior in Organization. Academy of Management Review, 7(3), 403-412.

Ferris, G. R., and Kacmar, K. M. (1992); Perceptions of Organizational Politics, Journal of Management, 18(1), 93-116.

Ferris, G. R., Bhawuk, D. P. S., Fedor, D. F., and Judge, T. A. (1995); Organizational Politics And Citizenship: Attributions of Intentionality and Construct Definition, Advances in Attribution Theory: An Organizational Perspective, 231-252.

Gandz, J., and Murray, V. V. (1980); The Experience of Workplace Politics, Academy of Management Journal, 23(2), 237-251.

Graves, L. M., Cullen, K. L., Lester, H. F., Ruderman, M. N., and Gentry, W. A. (2015); Managerial Motivational Profiles: Composition, Antecedents, and Consequences, Journal of Vocational Behavior, 87, 32-42.

Gray, B., and Ariss, S. S. (1985); Politics and Strategic Change Across Organizational Life Cycles, Academy of Management Review, 10(4), 707-723.

Hagger, M. S., and Chatzisarantis, N. L. (2005); First-and Higher-Order Models of Attitudes, Normative Influence, and Perceived Behavioral Control in the Theory of Planned Behaviour, British Journal of Social Psychology, 44(4), 513-535.

Hair, J.F. Jr., Anderson, R.E., Tatham, R.L., and Black, W.C. (1998); Multivariate Data Analysis, (5th Edition), Upper Saddle River, NJ: Prentice Hall.

Harrell-Cook, F., Ferris, G. and Dulebohn, J.H. (1999); Political Behaviors as Moderators of the Perceptions of Organizational Politics-Work Outcomes Relationships, Journal of Organizational Behavior, 20(7), 1093-1105.

Kacmar, K. M., and Carlson, D. S. (1997); Further Validation of The Perceptions of Politics Scale (POPS): A Multiple Sample Investigation, Journal of Management, 23(5), 627-658.

Kacmar, K. M., and Ferris, G. R. (1991); Perceptions of Organizational Politics Scale (POPS): Development and Construct Validation, Educational and Psychological Measurement, 51(1), 193-205.

Lau, P. Y. Y., Tong, J. L. T., Lien, B. Y. H., Hsu, Y. C., and Chong, C. L. (2017); Ethical Work Climate, Employee Commitment and Proactive Customer Service Performance: Test of The Mediating Effects of Organizational Politics, Journal of Retailing and Consumer Services, 35, 20-26.

Madison, D. L., Allen, R. W., Porter, L. W., Renwick, P. A., and Mayes, B. T. (1980); Organizational Politics: An Exploration of Managers' Perceptions, Human Relations, 33(2), 79-100.

Mayes, B. T., and Allen, R. W. (1977); Toward A Definition of Organizational Politics. Academy of Management Review, 2(4), 672-678.

Miles, R. H. (1980); Macro Organizational Behavior. Goodyear Pub. Co. 
Mintzberg, H. (1983); Power in and Around Organizations (Vol. 142). Englewood Cliffs, NJ: Prentice-Hall.

Mintzberg, H., and Waters, J. A. (1985); Of Strategies, Deliberate and Emergent. Strategic Management Journal, 6(3), 257-272.

Narayan, B., Rajendran, C., and Sai, L. P. (2008); Scales to Measure and Benchmark Service Quality in Tourism Industry: A Second-Order Factor Approach, Benchmarking: An International Journal, 15(4), 469-493.

Narayanan, V. K., and Fahey, L. (1982); The Micro-Politics of Strategy Formulation, Academy of Management Review, 7(1), 25-34.

Nasurdin, A. M., Ahmad, N. H., and Razalli, A. A. (2014); Politics, Justice, Stress, and Deviant Behaviour in Organizations: An Empirical Analysis, International Journal of Business and Society, 15(2), 235.

Parker, C. P., Dipboye, R. L., and Jackson, S. L. (1995); Perceptions of Organizational Politics: An Investigation of Antecedents and Consequences, Journal of Management, 21(5), 891-912.

Pfeffer, J., (1981); Power in Organizations (Vol. 33), Marshfield, MA: Pitman.

Pfeffer, J., and Salancik, G. R. (1974); Organizational Decision Making as A Political Process: The Case of A University Budget. Administrative Science Quarterly, 135-151.

Rindskopf, D., and Rose, T. (1988); Some Theory and Applications of Confirmatory Second-Order Factor Analysis, Multivariate Behavioral Research, 23(1), 51-67.

Saleem, H. (2015); The Impact of Leadership Styles on Job Satisfaction and Mediating Role of Perceived Organizational Politics, Procedia-Social and Behavioral Sciences, 172, 563-569.

Schein, V. E. (1977). Individual Power and Political Behaviors in Organizations: An Inadequately Explored Reality. Academy of Management Review, 2(1), 64-72.

Schermelleh-Engel, K., Moosbrugger, H., and Müller, H. (2003); Evaluating the Fit of Structural Equation Models: Tests of Significance and Descriptive Goodness-ofFit Measures, Methods of Psychological Research Online, 8(2), 23-74.

Thompson B (1989); Meta-Analysis of Factor Structure Studies: A Case Study Example With Bem's Androgyny Measure, The Journal of Experimental Education, 57 (2), 187-197.

Vigoda, E., and Cohen, A. (2002). Influence Tactics and Perceptions of Organizational Politics: A Longitudinal Study. Journal of Business Research, 55(4), 311-324.

Vigoda-Gadot, E., and Talmud, I. (2010); Organizational Politics and Job Outcomes: The Moderating Effect of Trust and Social Support, Journal of Applied Social Psychology, 40(11), 2829-2861.

Welsh, M. A., and Slusher, E. A. (1986); Organizational Design as A Context for Political Activity, Administrative Science Quarterly, 389-402.

Y1lmaz, E., Özer, G., and Günlük, M. (2014); Do Organizational Politics and Organizational Commitment Affect Budgetary Slack Creation in Public Organizations?, Procedia-Social and Behavioral Sciences, 150, 241-250.

Yilmaz, L. D. (2014); Perception of Organizational Politics and Impression Management Behaviors: A Tourism Industry Perspective, International Journal of Business and Social Science, 5(8). 